\title{
The Influence of External Environtmental Forces and Strategic Orientation on Value Creation and the Implication on Business Performance
}

\author{
Hana Suryana \\ Universitas Pendidikan Indonesia \\ hanasuryana.upi12@gmail.com
}

\begin{abstract}
The growth of business performance of courier service industry in Indonesia in the last five years is likely to stagnate. The percentage of target achievement of sales performance is still hard to achieve and profit growth is relatively small. This study aims to explore the data and information on External Environmental Forces and Strategic Orientation on Value Creation and their implication on Business Performance of courier service industry in Indonesia. The nature of this research is verification. The unit of analysis is the courier service industry, and a sample of 72 courier companies from various regions in Indonesia, which the branch office in Jakarta. Time horizon is cross-sectional, where the research is done at a certain time. The analysis is done by using the model verification Partial Least Square (PLS). The findings reveal that strategic orientation has a significant influence on value creation, while External Environmental Forces do not have a significant influence on value creation. Strategic orientation has a greater influence rather than External Environmental Forces in influencing business performance. Value creation has a greatest influence on business performance.
\end{abstract}

Keywords: External Environmental Forces, Strategic Orientation, Value Creation, Business Performance.

\section{INTRODUCTION}

\section{A. Research Background}

Indonesia has great opportunities for logistics service providers because most business segments have shown significant revenue growth in recent years. In addition, the growth of exports of goods and services in Indonesia which had increase approximately 9.7 to 10.8 percent in 2011 was also considered to be one of the factors driving the growth of the logistics and transportation industry in Indonesia.

Refer to the research of SWA [1]), one type of logistics services that most needed are Express and Courier Service, as many as $90 \%$, compared to other logistics services, specifically: air cargo of $60 \%, 55 \%$ ground transportation, shipping by sea $55 \%$, freight forwarding $45 \%$ and warehousing and distribution as of $45 \%$.

From the data [2], in 2009 the market size of couriers detected as much as the USD 10, 4 trillion, which was contested by the courier players as can be seen by; Tiki by $14.4 \%$, PT Pos Indonesia by $13.5 \%$, and $6 \%$ JNE the other players take control of $66.1 \%$. It shows us the market share of courier contested by local, regional and even global comparatively was very large.

\section{TABLE I.}

THE GROWTH OF BUSINESS PERFORMANCE OF COURIER INDUSTRY IN INDONESIA

\begin{tabular}{|c|c|c|c|c|c|c|}
\hline \multirow{2}{*}{$\begin{array}{c}\text { Num } \\
\text { ber }\end{array}$} & \multirow{2}{*}{$\begin{array}{c}\text { Business } \\
\text { Performance }\end{array}$} & \multicolumn{5}{|c|}{ Year } \\
\hline & & 2009 & 2010 & 2011 & 2012 & 2013 \\
\hline 1 & Sales Target & $\begin{array}{l}79,228 . \\
09\end{array}$ & $\begin{array}{l}97,657 . \\
86\end{array}$ & $\begin{array}{l}107,48 \\
0.82\end{array}$ & $\begin{array}{l}372,25 \\
0.8\end{array}$ & $\begin{array}{l}168,14 \\
6.64\end{array}$ \\
\hline \multirow[t]{2}{*}{2} & $\begin{array}{l}\text { Sales } \\
\text { Realization }\end{array}$ & $\begin{array}{l}72,298 . \\
93\end{array}$ & $\begin{array}{l}85,281 . \\
46\end{array}$ & $\begin{array}{l}101,87 \\
9.78\end{array}$ & $\begin{array}{l}121,83 \\
7.45\end{array}$ & $\begin{array}{l}150,25 \\
5.52\end{array}$ \\
\hline & $\begin{array}{l}\text { Percentage of } \\
\text { sales } \\
\text { Achievement }\end{array}$ & $91.3 \%$ & $87.3 \%$ & $94.8 \%$ & $88.8 \%$ & $89.4 \%$ \\
\hline 3 & Profit target & $5,802.41$ & $\begin{array}{l}7,427 . \\
75\end{array}$ & $\begin{array}{l}9,373 . \\
58\end{array}$ & $\begin{array}{l}10,414 . \\
48\end{array}$ & $\begin{array}{l}11,704 \\
74\end{array}$ \\
\hline \multirow[t]{2}{*}{4} & $\begin{array}{l}\text { Profit } \\
\text { realization }\end{array}$ & $5,442.87$ & $\begin{array}{l}5,826 . \\
38\end{array}$ & $\begin{array}{l}8,916 . \\
83\end{array}$ & $\begin{array}{l}10,586 . \\
99\end{array}$ & $\begin{array}{l}11,944 \\
94\end{array}$ \\
\hline & $\begin{array}{l}\text { Percentage of } \\
\text { profit } \\
\text { Achievement }\end{array}$ & $93.8 \%$ & $78.4 \%$ & $95.1 \%$ & $\begin{array}{l}101.7 \\
\%\end{array}$ & $\begin{array}{l}102.1 \\
\%\end{array}$ \\
\hline
\end{tabular}

a. Source: Association of Courier Services Company, processed (2014)

The data in the table revealed that the growth performance of courier services business in Indonesia within a period of five years did not experience a significant growth. This can be seen from the percentage of performance result. The Achievement of profit targets in the past two years have increased, but the increase was relatively small. Wheelen and Hunger [3] stated that, an optimum business performance could be achieved if the company has a high sales growth rate and profitability.

The low performance of the courier industry in Indonesia, due to weaknesses in value creation, because the resulting product tends not been fully focused to the demands of the market, there is no unique products that are more competitive compared to competitors' products, it is still hard to create products innovations that are difficult to duplicate by the competitors, yet the industrial cooperation with various stakeholders has not been closed, and companies are still weak in anticipating the changes in the business environment. Meanwhile, according to Kotler and Keller [4], value creation has three important steps that are creating benefits for customers, has a domain in business, and the creations of appropriate partnerships with different stakeholders. 
Besides, it is also due to the weakness of the strategic orientation [5], as the strategic review directions implemented by a firm to create the proper behaviors for the continuous superior performance. The managers are required to strategically orientation continuously with efforts such as: business performance improvement, increased revenue, operational cost efficiency, and innovation in overcoming the limitations, the development of integrated business.

According to preliminary survey the low performance of the business is because the management has not been fully able to adapt and anticipate the strength of the external environment. The company has to anticipate opportunities and threats, global economic conditions, government policies, demand of workers, and competition. Meanwhile, according to Wheelen \& Hunger [3] stated that the sustainability of the business is largely determined by the ability of the company's management in adapting and anticipating the strength of the macro external environment as well as micro external environment.

Based on the above, it is important to study about External Environment Forces and Strategic Orientation towards value creation and its impact on business performance in the courier industry in Indonesia.

\section{B. Literature Review}

Pearce \& Robinson [6], external environment can be divided into three inter related sub-categories; remote, industry and operation environment, which has to be managed before a company set up strategy formulation [3]. The external environment are factors beyond the company's control that can affect the selection, direction and action, organizational structure, and the company's internal processes. Changes in the external force may be changes in consumer demand for products and services of industrial and consumer. External forces affecting the types of products developed, the nature of promotion and market segmentation strategy, the type of services offered and the choice of the business to be bought or sold. David [7] stated that external forces can be divided into five broad categories ; (1) economic forces, (2) social, cultural, demographic, and environment forces, (3) political, governmental, and legal forces (4) technological forces, (5) competitive forces.

Strategic Orientation has to set up by the company as a direction to reach continuous superior performance $[5,8,9]$. The company also have to focus on strategic direction and proper strategic fit, considering organization structure, in other to win the competition to ensure superior firm performance $[10,8,11]$. Keep in best performance, market orientation and managing changes in mature business. [12, 13, 14].

Kotler and Keller [15] on value creation stated that to exploit a value opportunity, the company needs value-creation skills. Marketers need to identify new customer benefits from the customer's view; utilize core competencies from its business domain; select and manage business partners from its collaborative network. To craft new customer benefits, marketers must understand what the customer thinks about, wants, does, and worries about. Marketers must also observe who customers admire, who they interact with and who influences them. Not only customer focus [15], the company has to consider Value creation logic [16]

Business Performances [17], are indicator of how well does organization accomplish its goals [18]. As the output or result of the implementation of all activities related to business activities, and sales growth, market share and profitability are the indicators $[19,3]$.

\section{Research Objectives}

The purpose of this study is to explore the data and information about:

1) The influence of External Environment Forces and Strategic Orientation on value creation in the courier industry in Indonesia.

2) The influence of External Environment Forces and Strategic Orientation on business performance in the courier industry in Indonesia.

3) The influence of Value Creation on Business Performance in the courier industry in Indonesia.

\section{METHODOLOGY}

\section{A. Research Methods}

Given the nature of this research is verification, then research uses explanatory survey method. Type of investigations conducted is causalities for explaining an effect of one variable to another variable. Time horizon is cross sectional. Survey, interview and questionnaire.

The sampling technique used is stratified random sampling that divide population into groups, in this case the distribution of geographic regions. Sample size is as much as 72 courier companies operating in various regions in Indonesia most of the headquarters in Jakarta.

\section{B. Hypothesis Testing Design}

Verification analysis used to answer the hypothesis, by using Partial Least Square (PLS), a method for modeling relationships between variables set of observations through latent variables.

\section{DISCUSSION}

\section{A. Goodness of Fit Model}

\section{1) Analyis of Measurement Model of External} Environtment Forces

Based on the output of Smart PLS, the results shows that all indicators are valid with loading factor value greater than 0.50 . In addition to valid, all indicators inferred to have high reliability with the reliability of composite values greater than 0.700 . 
All dimensions used to measure variable of Environment External Forces has a loading factor value greater than 0.50 , so we can conclude they are valid. These three dimensions have Composite reliability value greater than 0.700 that the three dimensions can be inferred reliably.

2) The Analysis of Measurement Model of Strategic Orientation

The results of the measurement model of Strategic Orientation dimensions shows that all indicators are valid with loading factor value greater than 0.50 . In addition to valid, all indicators inferred to have high reliability with the composite reliability values greater than 0.700 .

All dimensions used to measure the Strategic Orientation variable has a value of loading factor greater than 0.50 so we can conclude as valid. Four dimensions generate Composite reliability values greater than 0.700 , so that the four dimensions can be inferred reliably.

\section{3) The Analysis of Measurement Model of Value Creation}

Based on the output of Smart PLS, the results shows that all indicators are valid with loading factor value greater than 0.50 . In addition to valid, all indicators inferred to have high reliability with the reliability of composite values greater than 0.700 .

All dimensions used to measure variable Value Creation has a loading factor value greater than 0.50 (or the value of the t statistic> 1.99) so that it can be concluded as valid. Four dimension generate Composite reliability values greater than 0.700 so that the four dimensions can be inferred reliably.

\section{B. The Analysis of Structural Model (Inner Model)}

After the Outer Model be valid and reliable, then conduct a structural models (Inner model) testing of the complete model. This complete model brings together all of the variables that have reduced invalid indicators. Here are the values of RSquare on the construct: Structural Model on PLS evaluate using Goodness of Fit model, which shows the difference between the observed values and the values predicted by the model.

TABLE II.

STRUCTURAL MODEL TeSTING (INNER MODEL)

\begin{tabular}{|l|l|l|l|l|l|}
\hline \multicolumn{1}{|c|}{$\begin{array}{c}\text { Latent } \\
\text { Variable }\end{array}$} & AVE & $\begin{array}{c}\text { Cronbachs } \\
\text { Alpha }\end{array}$ & Communality & $\begin{array}{c}\text { R } \\
\text { Square }\end{array}$ & GOF \\
\hline External Env & 0.605 & 0.948 & 0.605 & \multirow{2}{*}{0,789} \\
\hline $\begin{array}{l}\text { Strategic } \\
\text { Orientation }\end{array}$ & 0.784 & 0.987 & 0.784 & 0.891 & \\
\hline $\begin{array}{l}\text { Value } \\
\text { Creation }\end{array}$ & 0.737 & 0.983 & 0.737 & 0.790 & \\
\hline $\begin{array}{l}\text { Business } \\
\text { Performances }\end{array}$ & 0.833 & 0.900 & 0.833 & \\
\hline
\end{tabular}

Source: OUTPUT SmartPLS

The discriminant validity appraised from the value of square root of average variance extracted (AVE).
Recommended value is above 0.5. The table above gives AVE values above 0.5 for all constructs contained in the research model,

Test reliability is reinforced by Cronbach's Alpha (suggested value is above 0.6). Reliability results will indicate satisfactory if a score above 0.7. From the table above it is known that Cronbach's Alpha for all variables> 0.7. Thereby reinforcing the test results, that the measurement model to four of these variables had been consistency and accuracy in measuring the construct.

The R-squared $\left(\mathrm{R}^{2}\right)$ Test aims to determine how well the inner model (structural model) were formed. According to Ghozali [21], the $\mathrm{R}^{2}$ value of 0.67 (means good), 0.33 (means moderately) and 0.19 (weak) to endogenous latent variables in the inner model. This study has a value of $\mathrm{R}$-squared $\left(\mathrm{R}^{2}\right)$ Lowest $=0.790$. It showed that it has a good inner model, as well as GOF value of 0.789 so it can be concluded that the research model supported by empirical conditions or model fit.

TABLE III.

INNER MODEL EQUATION

\begin{tabular}{|c|c|c|c|c|}
\hline Inner Model & $\gamma$ & $\begin{array}{c}\text { Standard } \\
\text { Error } \\
\text { (STERR) }\end{array}$ & $\begin{array}{c}\mathbf{T} \\
\text { Statistics } \\
(\mid \gamma \\
\text { /STERR })\end{array}$ & Model Equation \\
\hline $\begin{array}{c}\text { External Env } \\
\text {-> Value } \\
\text { Creation }\end{array}$ & 0.114 & 0.085 & 1.332 & \multirow[b]{2}{*}{$\mathrm{VC}=0.114 \mathrm{EEF}+0.844 \mathrm{SO}+\zeta 1$} \\
\hline $\begin{array}{c}\text { Strategic } \\
\text { Orientation - } \\
>\text { Value } \\
\text { Creation }\end{array}$ & 0.844 & 0.078 & 10.762 & \\
\hline $\begin{array}{l}\text { External Env } \\
->\text { Business } \\
\text { Performances }\end{array}$ & 0.182 & 0.080 & 2.281 & \multirow{3}{*}{$\begin{array}{r}\mathrm{BP}=0.182 \mathrm{EEF}+0.302 \mathrm{SO} \\
+0.435 \mathrm{VC}+\zeta 2\end{array}$} \\
\hline $\begin{array}{l}\text { Strategic } \\
\text { Orientation - } \\
\text { > Business } \\
\text { Performances }\end{array}$ & 0.302 & 0.138 & 2.193 & \\
\hline $\begin{array}{l}\text { Value } \\
\text { Creation -> } \\
\text { Business } \\
\text { Performances }\end{array}$ & 0.435 & 0.135 & 3.226 & \\
\hline
\end{tabular}

Source : OUTPUT SmartPLS

\section{Hypothesis Testing}

1) Hypothesis 1 : There is an influence of External Environtment Forces and Strategic Orientation on Value Creation

TABLE IV

TESTING OF HYPOTHESIS 1

\begin{tabular}{|l|l|l|l|l|}
\hline \multicolumn{1}{|c|}{ Hypothesis } & $\boldsymbol{\gamma}$ & $\begin{array}{c}\text { Standard } \\
\text { Error } \\
\text { (STERR) }\end{array}$ & $\begin{array}{c}\text { T } \\
\text { Statistics } \\
(\mid \boldsymbol{\gamma} \\
\text { /STERR|) }\end{array}$ & $\mathbf{R}^{\mathbf{2}}$ \\
\hline $\begin{array}{l}\text { External Env -> } \\
\text { Value Creation }\end{array}$ & 0.114 & 0.085 & 1.332 & \multirow{2}{*}{0.891} \\
\hline $\begin{array}{l}\text { Strategic } \\
\text { Orientation -> } \\
\text { Value Creation }\end{array}$ & 0.844 & 0.078 & $10.762^{*}$ & \\
\hline
\end{tabular}

The test results showed that the Strategic Orientation has a greater and significant influence on Value Creation in the 
courier service industry in Indonesia, while the External Environment is not significant $(\mathrm{t}<1.99)$.

2) Hypothesis 2 : There is an influence of External Environtment Forces and Strategic Orientation on Business Performances

TABLE $V$.

TESTING OF HYPOTHESIS 2

\begin{tabular}{|l|l|l|l|l|}
\hline \multicolumn{1}{|c|}{ Hypothesis } & $\gamma$ & $\begin{array}{c}\text { Standard } \\
\text { Error } \\
\text { (STERR) }\end{array}$ & $\begin{array}{c}\mathbf{T} \\
\text { Statistics } \\
(\mid \gamma \\
\text { /STERR) }\end{array}$ & $\mathbf{R}^{2}$ \\
\hline $\begin{array}{l}\text { External Env - } \\
\begin{array}{l}\text { Business } \\
\text { Performances }\end{array}\end{array}$ & 0.182 & 0.080 & $2.281^{*}$ & \multirow{2}{*}{0,220} \\
\hline $\begin{array}{l}\text { Strategic } \\
\text { Orientation -> } \\
\text { Business } \\
\text { Performances }\end{array}$ & 0.302 & 0.138 & $2.193^{*}$ & \\
\hline
\end{tabular}

Significant at $\alpha=0,05$

The test results showed that the External Environment Forces and Strategic Orientation influence on Business Performances in the courier service industry in Indonesia, with the effect of of $22 \%$ and Strategic Orientation has greater influence.

3) Hypothesis 3 : There is an influence of Value Creation on Business Performances

TABLE VI.

TESTING OF HYPOTHESIS 3

\begin{tabular}{|l|l|l|l|l|}
\hline \multicolumn{1}{|c|}{ Hypothesis } & $\beta$ & $\begin{array}{c}\text { Standard } \\
\text { Error } \\
\text { (STERR) }\end{array}$ & $\begin{array}{c}\text { T } \\
\text { Statistics } \\
(\mid \boldsymbol{\gamma} \\
\text { /STERR|) }\end{array}$ & $\mathbf{R}^{\mathbf{2}}$ \\
\hline $\begin{array}{l}\text { Value } \\
\begin{array}{l}\text { Creation } \rightarrow \\
\text { Business } \\
\text { Performances }\end{array}\end{array}$ & 0.435 & 0.135 & $3.226^{*}$ & 0,189 \\
\hline
\end{tabular}

Significan at $\alpha=0,05$

The test results showed that the Value Creation significantly influence Business Performances in the courier service industry in Indonesia with the effect of 18.9

Hypothesis testing results show that value creation has a dominant influence in improving business performance in the courier industry in Indonesia. In the variable value creation, business partner is the dimension of the highest influence on the business performance of the courier service industry in Indonesia, followed by the dimensions of the domain business and customer benefit.

Based on the results of hypothesis testing, it can be concluded that the business performance improvement of courier industry is predominantly influenced by the implementation of value creation mainly business partner by management of courier services company. Business partners implemented by some courier company through the opening of the agency system, such as PT POS, JNE, TIKI, RPX and others. The pattern of the agency as it can provide benefits to the company.
Hypothesis testing results show that the creation of value, more dominantly influenced by the strategic orientation. Meanwhile, the variable of the external environment forces, not having significant effect to value creation. Dimensions of the highest influence in reflecting the strategic orientations are: customer orientation, followed by interfunctional coordination, entrepreneurial orientation, and competitor orientation. In this case indicated that the creation of value is influenced predominantly by the extent to which the company is able to develop its customer orientation. Customers in the business of courier services have a strong enough force because the many players in this industry so makes it easy for customers to select a courier service which will be used. Thereby the customer's trust must be maintained by the courier company.

The influence of the creation of value to business performance, in this study, supporting the research of Ndubisi Matanda [23], the suppliers perceived value creation mediates the relationship between market orientation and business performance. The creation of value perceived by suppliers are also positively related to performance marketing. Next is the study Teixeira and Amaro [24], which shows the relationship between financial performance and ability to create value in organizations and the need of vision to value creation [25].

\section{CONCLUSION AND RECOMMENDATION}

There is influence of External Environment Forces and Value Creation on Business Performance, Value Creation has significantly influenced Business Performance. On the other there is no significant influence of External Environment Forces on Value Creation in courier services in Indonesia.

The research findings in this paper, is expected to be a reference for academics to conduct research development, wherein the results of these findings can be made as part of the premise in preparing the framework.

Future research is recommended to conduct in the field of strategic management and the manufacturing as well as banking industry as unit analysis.

\section{REFERENCES}

[1] SWA Magazine, Research on Logistic Business, September 2011.

[2] Booz \& Co, Fact Finding on Final Report to Pos Indonesia, 2010.

[3] R Thomas L., Wheelen, \& Hunger, J. D., Strategic management and business policy: toward global sustainability. Pearson/Prentice Hall, 2012.

[4] Kotler, P., \& Keller, K. L. (2012). Marketing Management., New Jersey, US: Pearson Education, 2012.

[5] Toften. K.. \& Hammervoll. T.. Strategic orientation of niche firms. Journal of Research in Marketing and Entrepreneurship, 12 (2), 2010, 108-121.

[6] Pearce, J. A., Robinson, R. B., \& Subramanian, R. Strategic management: Formulation, implementation, and control. Chicago, Illinois: Irwin, 1997.

[7] David, Fred., R, Strategic Management, Concept \& Cases, Pearson Education Limited, England, 2013

[8] Gatignon. H.. \& Xuereh. I. M.. Strategic orientation of the firm and new product performance. Journal of marketing research, 1997, 77-90.

[9] Hitt, M. A., Dacin, M. T., Tyler, B. B., \& Park, D., Research notes and communications understanding the differences in Korean and US 
executives' strategic orientations. Strategic management journal, 18(2), 1997, 159-167.

[10] Weinzimmer, L. G., Robin, J., \& Michel, E. J. ,The measurement of strateoic orientation and its efficacv in nredicting financial performance. Journal of Business Strategies, 29(2), 2012, 81.

[11] Pleshko, L., \& Nickerson, I. (2008). Strategic orientation, organizational structure, and the associated effects on performance in industrial firms. Academy of Strategic Management Journal,7,2008, 95.

[12] Miller, D., \& Friesen, P. H., Porter's generic strategies and performance: An emnirical examination with American data Part I: Testing Porter. Organization studies, 7(1), 1986,1980, 37-55.

[13] Whinn. R.. Rosenfeld. R.. \& Pettigrew. A.. Managing strategic change in a mature business. Long Range Planning, 22(6), 1980, 92-99.

[14] Cadogan*II, J. W., \& Diamantopoulos \$, A., Narver and Slater, Kohli and Jaworski and the market orientation construct: integration and internationalization. Journal of strategic marketing, 3(1), 1995, 41-60.

[15] Kotler. P.. Keller. K. L.. Koshv. A.. \& Jha. M.. Creation Customer Value Satisfaction and loyalty. Marketing management, 13, 2009, 120-125.

[16] Othman, Rozham and Sheelan, Norman T.,2011, Value Creation Logics and Resource Management: A Review, Proquest

[17] Matić, I., \& Jukić, V.,Innovativeness and Business Performances: Emnirical Evidence from Bosnia and Herzegovina's Small Sized Firms. The Journal of American Academy of Business, Cambridge, 18(1), 2012, 198-205.
[18] Venkatraman, N., \& Ramanujam, V., Measurement of business nerformance in strategv research: A comnarison of approaches. Academy of management review, 11(4), 1986, 801-814.

[19] Best, R., Market-based management. Pearson Higher Ed, 2012.

[20] Ghozali. I. Structural Eauation Modeling Metode Alternatif dengan Partial Least Square. Semarang: Badan Penerbit Universitas Diponegoro, 2008.

[21] Ghozali. I.. Structural Eauation Modeling: alternative method with Partial Least Square (PLS). Semarang, Indonesia, 2008.

[22] Bing, L. I. U., \& Zhengping, F. U., Relationship between strategic orientation and organizational nerformance in born global: a critical review.International Journal of Business and Management, 6(3), 2011, 109

[23] Jekanyika Matanda, M., \& Oly Ndubisi, N.,Market orientation, supplier nerceived value and business nerformance of SMEs in a Sub-Saharan African nation. Journal of Enterprise Information Management, 22(4), 2009, 384-407.

[24] Teixeira. N. M. D.. \& Amaro. A. G. C. (2013). Evaluation of Financial Performance and Value Creation-A Case Study. Revista Universo Contabil,9(4), 2013, 157.

[25] Rodgers, Davd E., Vision-To-Value Creation: A Balanced Fit Strategic Dynamic Capability Process, Capella University, Proquest, UMI Disertation Publishing, 2010. 